\title{
Bivalve aquaculture transfers in Atlantic Europe. Part A: Transfer activities and legal framework
}

\author{
F. Muehlbauer, ${ }^{a, b}$, D. Fraser ${ }^{c}$, M. Brenner ${ }^{d, *}$, K. Van Nieuwenhove ${ }^{e}$, B.H. Buck ${ }^{d, f}$, O. Strand ${ }^{g}$, \\ J. Mazuriée $^{h}$, G. Thorarinsdottir ${ }^{i}$, P. Dolmer ${ }^{j}$, F. O`Beirn ${ }^{k}$, A. Sanchez-Matal, G. Flimlin ${ }^{m}$, P. Kamermans ${ }^{n}$ \\ a University of Rostock, Department of State and Administrative Law, Environmental Law and Public Economic \\ Law, 18051 Rostock, Germany \\ ${ }^{b}$ Department of Aquaculture and Searanching, Justus-von-Liebig-Weg 6, 18059 Rostock, Germany \\ ${ }^{c}$ Fisheries Research Services, Marine Laboratory, 375 Victoria Road, Aberdeen AB11 9DB, UK \\ d Alfred Wegener Institute Helmholtz Centre for Polar and Marine Research (AWI), Am Handelshafen 12, 27570 \\ Bremerhaven, Germany \\ e Institute for Agricultural and Fisheries Research (ILVO), Ankerstraat 1, 8400 Oostende, Belgium \\ ${ }^{\dagger}$ Maritime Technologies, University of Applied Sciences, An der Karlstadt 8, 27568 Bremerhaven, Germany \\ ${ }^{g}$ Institute of Marine Research, Nordnesgt. 50 Boks, 1870 Nordnes, N-5817 Bergen, Norway \\ ${ }^{\mathrm{h}}$ French Research Institute for the Exploitation of the Sea (IFREMER), 12 rue des Resistants, B.P. 86, 56470 La \\ Trinité-sur-Mer, France \\ i Marine Research Institute, Skulagata 4, 121 Reykjavik, Iceland \\ j Technical University of Denmark, National institute of Aquatic Resources - DTU Aqua, Jægersborg Alle 1, DK- \\ 2920 Charlottenlund, Denmark \\ ${ }^{\mathrm{k}}$ Marine Institute, Rinville, Oranmore, Galway, Ireland \\ I Centre for Marine Research (CIMA), PO Box 13, 36620 Vilanova de Arousa, Spain \\ ${ }^{m}$ Rutgers Cooperative Extension, 1623 Whitesville Road, Toms River, NJ 08755, USA \\ ${ }^{n}$ Institute for Marine Resources and Ecosystem Studies (IMARES), PO Box 77, 4400 AB Yerseke, The \\ Netherlands
}

\author{
*: Corresponding author: M. Brenner, tel.: +49 47148311034 ; fax: +49 47148311149 ; email address : \\ Matthias.Brenner@awi.de \\ florian.muehlbauer@uni-rostock.de ; david.fraser2@scotland.gsi.gov.uk ; kris.van.nieuwenhove@gmail.com ; \\ Bela.H.Buck@awi.de ; oivind.strand@imr.no ; Joseph.Mazurie@ifremer.fr ; qutho@hafro.is ; pdo@aqua.dtu.dk ; \\ Francis.obeirn@marine.ie ; adoracion.sanchez@usc.es ; flimlin@AESOP.Rutgers.edu ; \\ flimlin@AESOP.Rutgers.edu ; Pauline.Kamermans@wur.nl
}

\begin{abstract}
:
Intentional transfers of numerous bivalve species have had a long tradition and are commonly conducted along the European Atlantic coast. However numerous studies have concluded that intentional transfer of species for aquaculture purposes is one of the most principal vectors for the introduction of exotic species around the world. Threats due to the transfer and introduction of species have been identified and a range of global and regional agreements, guidelines, standards and statutes to minimize effects have been established. Yet whether such regulations can protect and conserve the marine environment and address economic considerations remains unanswered. This study provides the first overview of bivalve transfer activities for aquaculture purposes along the European Atlantic coast. Existing international and EU legislation is described, and potential weaknesses in the existing legislative frameworks are discussed. Recommendations for the development of integrated risk assessment methods are given. These may help to minimize the intrinsic threats of transfer activities in marine environments. The resulting impacts and effects of transfer activities of bivalves for aquaculture purpose are addressed in detail in a companion paper.
\end{abstract}




\section{Highlights}

We give first overview about the transfer activities in Atlantic European countries. We provide first comprehensive review of the existing guidelines and legislation. We evaluate strength and weaknesses of the legal framework. We provide detailed recommendations for industry and policy makers. 


\section{Introduction}

Invading marine species were first introduced by early explorers and tradesmen, both intentionally as sources of food and unintentionally through for example fouling on the hulls of wooden ships or ballast dumping. In more recent times, the transfer mechanisms by which marine invaders travel and spread are widespread, numerous and varied. A prevalent mechanism is the transport of species in ships for aquaculture purposes (principally intentional introductions), such as the trade in pets or live seafood e.g. mussels from South Africa, North America and Pacific Asia (Branch \& Steffani 2004; Heath et al. 1995; Skurikhina et al. 2001). However, a majority of species are introduced unintentionally. It remains difficult to predict whether a nonindigenous aquatic species can survive and reproduce in a new environment and, if so, to correctly determine potential harm to the environment. However, evidence is building that some nonindigenous species have become permanent and invasive inhabitants of new ecosystems and the disadvantages are becoming clear and significant. Problems vary and may include the competitive displacement of native species (Laruelle et al. 1994), aesthetic impact and fouling of gear (Carman et al. 2010), or more dangerously, severely adverse environmental impact, economic loss and risk to human health (Grigorakis \& Rigos 2011).

The movement of bivalves from one location to another by humans for aquaculture purposes can be usefully categorized into two terms transfers and introductions (Beaumont 2000). A transfer, or movement within a species' range, would include the restocking of a habitat once known to have been occupied by a particular species. In contrast, the movement of individuals outside of that species' range is referred to as an introduction. Transfers and introductions can be intentional i.e. the deliberate introduction of an exotic or indigenous species into an area for aquaculture purposes (a "target" species), or inadvertent, when such species are either associated with an introduced organism or their translocation is facilitated by aquaculture activities (McKindsey et al. 2007). These may include both "hitchhiking" species and disease causing organisms, i.e. species that grow in association with or may be transfered with cultured bivalves (Forrest et al. 2009).

Nowadays, the intentional transfer of e.g. bivalves for aquaculture purpose is one of the main vectors for the introduction of exotic species around the world (DFO 2006). However, the management of impacts related to the transfer of aquaculture products is a relatively new endeavour and details of movements between or within countries are notoriously hard to collate, mainly as there is, to date, no universal transfer recording system. Most countries involved in bivalve aquaculture are facing problems related to the impact of transfers, since these activities have been practised widely for decades or even centuries. Transfers of bivalves may take place on different scales, either within shellfish harvesting areas (local), between areas within a region or country (national), between countries within economic regions (Europe; regional), or internationally between economic regions (international/worldwide). In general, the main producers and distributers of bivalves are responsible for most transfer activities. They achieve the highest economic profit from these activities; however, also face the highest risk from the introduction of non-target invasive species to their coastal ecosystems.

This study offers the first overview of bivalve transfer activities for aquaculture purposes along the European Atlantic coast. A detailed review of existing international and EU legislation is also provided. As international policies have begun to address potential threats due to the transfer and introduction of species, global and regional agreements as well as guidelines and standards have been established by EU legislation. But is this sufficient to prevent adverse environmental impact caused by bivalve transfers? To help answer this question all relevant legislation from global international law, to regional and national regulations are described, as well as the current legal status and potential weaknesses in the oversight framework.

The introduction of non-indigenous invasive species or fouling organisms includes toxic algae, viruses, bacteria, disease agents, parasites, or the same species with a different genetic makeup. The latter can lead to an intermixing of wild and cultured or indigenous and introduced stocks potentially resulting in: reduced genetic integrity, subsequently poor recruitment and productivity, as well as factors including sterilization, reduced fitness, meat yield and fecundity. More details about the potential impacts and effects are addressed in a companion paper (Brenner et al., 2014, in press). 


\section{Transfer activities in Atlantic Europe}

All countries along the European Atlantic coast involved in the cultivation of bivalves are currently conducting transfer activities, however, in different ways and varying quantities (Tab. 1). These activities include transfers at all life stages from larvae to sexually mature individuals, from field sites to wild fishery sites or from field to culture sites, from shore to onshore facilities or from nearshore wild bottom beds to offshore hanging cultivation devices. The objectives of the transfer activities are always economic. Shellfish producers intend to organise food supply, to replenish a depleted stock, to enhance production, to relay bivalve for fattening purpose or keep shellfish fresh and alive prior to consumption. While being transferred, organisms may cross international and/or ecological boundaries. This is particularly true for countries such as France and Spain which have a long bivalve cultivation tradition; here well-established trade connections to neighbouring countries and along the coastlines of the Atlantic Ocean and Mediterranean exist where bivalve cultivation is conducted and transfers of all stages of the culture organisms are part of the cultivation process (e.g. hatcheries, refining processes, etc.). In other countries such as Belgium and Germany cultivation is focused on only a few species and transfer activities are limited to local scales, where mussels are e.g. fished from wild beds and transfered to cultivation plots close by (Tab. 1).

\section{Portugal}

Portugal has for many centuries cultivated only clams (Venerupis decussatus) on a commercial scale. Total annual bivalve production can reach several thousand tons under favourable conditions (Campos \& Cachola 2006a). Ninety-percent of the total production is achieved in southern Portugal at the Algarve coast (DGRM 2010). Most of the shellfish are sold locally, the remainder sold to markets in other western European countries, particularly Spain. Cultivation takes place mainly on intertidal bottom culture beds located in the Ria de Alvor, the Ria Formosa Lagoon systems, and the Arade Estuary (DGRM 2010). Due to the lack of hatcheries, seed is almost exclusively collected from wild banks and transfered to cultivation plots for grow-out. In an attempt to maintain competitiveness on the open market with other national and international bivalve production regions, seeds and adults of the Japanese carpet-shell Ruditapes philippinarum have been imported from abroad from the late 1980's by Portuguese growers to e.g. the Ria Formosa Lagoon. This transfer practice was repeated more recently with quantities of up to several hundred tons (Campos \& Cachola 2006b). However, total production of $R$. philippinarum at the Algarve has remained low and the environmental impact resulting from the transfer activities has been considered to be of minor importance. Yet a more severe impact regarding the Japanese carpet ( $R$. philippinarum) shell are now being reported from the Targus estuary further north. Here, the population increased dramatically, although carpet shells were not cultivated in the area.

\section{Spain}

In Spain, bivalve aquaculture production has focussed on mussels (Mytilus galloprovincialis). Other species, such as carpet shells ( $R$. philippinarum and $V$. decussatus) and oysters (Crassostrea gigas and Ostrea edulis) are cultivated only on a small scale. Main transfer activities encompass the translocation of mussel spat from natural sites to growing rafts and from clam spat produced in hatcheries and subsequently taken to onshore parks for grow out. Further, mussel spat originating from Galicia is also used to supply cultivation areas at Menorca and Mallorca in the Mediterranean. In addition to these local and national shellfish transfers, variable spat amounts are transfered from Italy (Japanese carpet-shell, R. philippinarum), France (flat oyster, O. edulis), Portugal (carpet-shell, V. decussatus) and Scotland (flat and Pacific oyster, O. edulis and C. gigas), destined mainly for hatcheries and culture parks in the Galician region.

\section{France}

In France, cultivation of bivalves is focussed on the Pacific Oysters ( $C$. gigas), and the two mussels species Mytilus edulis and M. galloprovincialis. According to the Comité National de la Conchyliculture production in the season 2010/2011 was about 84.000 tons of oysters (including 1300 tons of flat oysters) and about 73.900 tons of mussels (both species). According to statistics obtained from 
French customs, international exchanges of live molluscs within Europe are increasing. About 44.000 tons of mussels were transfered from several European countries such as Netherlands, Spain, Ireland, Italy, and Greece to French markets, not for re-immersion but for reconditioning in purification tanks. Oyster spat is being transfered from French hatcheries to several EU countries for cultivation purposes. In addition, cupped oysters are occasionally transfered from Ireland to France (e.g. 3200 tons in 2006) or from France to other European countries, mainly Italy. However, most transfers are conducted between French regions. Spat of the Pacific oyster (C. gigas) is collected in the Arcachon and Marennes-Oléron basins and then transfered to growing sites along the coasts of Brittany, Normandy and also along the Mediterranean. In addition, oyster spat from hatcheries is currently transfered all over the country. Market sized oysters are occasionally re-transfered from growing sites to Marennes-Oléron for refining purposes in claires. Transfers of flat oysters $(O$. edulis) occur mainly from spat collection sites in west and south Brittany to grow-out sites in north-east Brittany. Mussel spat is mainly collected from the South-Loire region and cultivated locally or transfered to the principle rearing sites in North Brittany or Normandy. Market sized mussels are usually delivered directly to the consumers; however, re-immersions in other regions may take place prior to market supply. According to the Directive (EC) 2006/88 on animal health, flat oysters (O. edulis) suspected of being infected by Bonamia and/or Marteilia sp.were excluded from transfer activities. More recently, oyster spat exhibiting abnormal mortality rates, most probably due to the presence of the OsHV-1 virus, has been banned for any transfers purposes (e.g. to Normandy).

\section{Belgium}

In Belgium, only naturally settled mussel spat ( $M$. edulis) obtained by suspended cultivation methods is permitted for mussel cultivation in areas of the North Sea. No regulations exist regarding transfers of spat or adult mussels between the cultivation areas. Apart from the cultivation of blue mussels, small scale cultivation of the Pacific and flat oysters are conducted near Ostend, supplied by French hatcheries and local spat.

Ireland

Shellfish production in Ireland is dominated by the production of the Pacific oyster (C. gigas) and the blue mussel (M. edulis). Production of blue mussel is divided into rope and bottom production. For rope mussel culture, transfer movements are limited whereby the seed is typically sourced using collection devices in the bays of cultures and grown through the full production cycle. In some instances, where areas have had prolonged closures due to harmful algal blooms, some stock is relocated from the rope mussel bays (mainly on the west coast) to bays used for bottom mussel culture (east and southeast coast). In contrast, the culture of mussels on the seafloor typically involves considerable movement of product at various stages in the production cycle. Bottom mussel culture is carried out predominantly on the east (and southeast) and north coast of the country. Seed is generally sourced from ephemeral beds in the Irish Sea (open water) and moved into the culture plots. In addition, given increasing demands for seed from producers, applications to import seed from areas outside the jurisdiction (Great Britain) have been submitted. Following a grow-out period mussels are exported to other jurisdictions either directly to market or for further production. In particular there is an important export market of bottom mussels from a number of bottom growing bays to the Netherlands. Oyster production in Ireland is concentrated on the south west and northwest coasts of Ireland. Seed is generally translocated from hatcheries in the United Kingdom and France. Production is carried out predominantly in bags and trestles, although some production is conducted uncontained on the subtidal bottom. While some oysters are sold to internal markets (restaurant trade), the majority of oysters are sold to France. Some of these go directly to market while the majority are relayed for further conditioning in French waters.

\section{United Kingdom}

Similarly to Ireland, the main cultivation species of the UK are mussels, Pacific oysters (C. gigas), native oysters ( $O$. edulis), scallops (Pecten maximus) and clams ( $V$. decussatus). Pacific oysters and clams are produced in hatcheries and are transfered to growout sites, while native oysters, scallops and mussels generally originate from wild stocks. 
Netherlands

In the Netherlands, blue mussels ( $M$. edulis) are cultivated in two separate areas; the Wadden Sea and the Oosterschelde estuary. In the Wadden Sea, mussel seed is fished from wild beds or collected with suspended ropes or nets. The growout of mussels to market size is conducted using on-bottom cultivation methods. In contrast, the Oosterschelde is not only a production area but also a relaying area for mussels transfered from other places to be sold at the international auction at Yerseke. Since production in the Netherlands does not meet the demand for mussels, seed and adult mussels are transfered from other European countries. Transfer of bivalves into the Wadden Sea, except for mussels from the German parts of the Wadden Sea, is not permitted. Mussels and spat from boreal areas (from the English Channel to the south of Norway and Sweden) can be transfered to the Oosterschelde, with permission. No permission is needed for the transfer of mussels and spat from the Dutch part of the Wadden Sea into the Oosterschelde. Vice versa, a transfer of mussels from the Oosterschelde to the Wadden Sea is not allowed. However, exemption is possible when an inventory of species associated with shellfish is carried out in the area of origin of the shellfish and a monitoring protocol of the transports is provided. Transfer of molluscs from outside the boreal area into the Oosterschelde is not permitted. Wijsman \& Smaal (2006) and Wijsman et al. (2007a; b) reviewed the risks of transport of mussels from Ireland, the UK, Sweden and Norway to the Dutch production areas. Based on the results of the study, a permit was given to the corporation of shellfish importers to import mussels and oysters from 12 production areas in Ireland and the UK into the Oosterschelde. The import of mussels destined for human consumption from these areas are (currently) monitored for the presence of exotic species by means of regular sampling upon arrival in Yerseke. Similar studies have been conducted by Wijsman et al. (2007a; b) and Wijsman and Mesel (2008) on the risks of transporting mussels from Norway, Sweden and Denmark to the Dutch Wadden Sea. The same exemption as mentioned above for transfers from the Oosterschelde to the Wadden Sea is possible for transfers from Norway, Sweden and Denmark. Oysters (C. gigas and $O$. edulis) are produced in the Grevelingen and Oosterschelde. Spat is collected locally and produced at pilot scale in a hatchery.

\section{Germany}

Similarly to the Netherlands, cultivation efforts in Germany are focussed almost exclusively on blue mussels ( $M$. edulis). Besides some small scale rope cultures, most mussels are cultivated on-bottom, supplied by fished wild seed mussels. Transfer activities are conducted on local, national and regional levels, either for cultivation or selling purposes. Seed mussels are transfered locally by the fishermen from their natural wild beds or suspended culture ropes to the licensed cultivation plots. On a regional scale several thousand tons per year of mussel spat have been transfered, owing to poor recruitment and failed spatfall in recent years within the German Bight. Spat has been transfered from the Netherlands, UK, Denmark and Ireland to German culture plots. The majority of mussel spat is derived from the British Channel and North Sea islands. However, according to the responsible authorities in Lower Saxony and Schleswig-Holstein transfer activities were stopped in 2006, mostly due to economic reasons, since the mortality rate of transfered spat was high and growth rates on the culture plots remained poor. All activities are conducted legally within the Wadden Sea National Parks, based on exploitation rights warranted before the area was rededicated as a nature reserve. Live marketsized mussels are exclusively transfered from Germany mainly to the Netherlands, France and Belgium. There, mussels are sometimes relayed e.g. to the Oosterschelde (NL) until they are sold on the market. Oyster farming is a very small scale business in Germany. The only commercial farm is located on the island of Sylt where oysters (C. gigas) are grown from spat originating from Ireland

\section{Denmark}

In Denmark, transfer of bivalves takes place in the Limfjord in the North of the country using bottom cultivation technics. The Limfjord is classified as a Marteilia and Bonamia approved zone and transfers into the zone are restricted. A processing of mussels from outside the zone is not permitted as there are no systems to handle the process water. In the Limfjord, regulation of the mussel fishery allows a bycatch of ca. $30 \%$ (wet-weight) mussels with a shell-length under $4.5 \mathrm{~cm}$ (minimum legal size). After processing, mussels below minimum legal size are discarded and have to be relayed to designated bottom cultivation areas. In addition to the relaying practice, mussel seed is transfered from wild areas 
with a high density to bottom cultivation areas. These fishing areas include Natura 2000 sites, where seed fishery permitting is based on an Environmental Impact Assessment. Mussel spat (M. edulis) produced on long-lines in the Limfjord is transfered to the east coast of Jutland and relayed in bottom culture, however only on an experimental scale.

\section{Sweden}

Mussel production in Sweden is concentrated on the west coast (Skagerrak) of the country. Due to the regular occurrence of algal toxins and low local consumption, mussel ( $M$. edulis) production has remained low and only approximately 1000 to 2000 tons of blue mussels are harvested per year (Lindahl \& Kollberg 2008). Transfer activities are rare, since production is based on submerged longline systems, supplied by natural spat from the water column. About half of the production is consumed locally. The rest is exported to other European countries, and potentially relayed prior to consumption. Plans exist to increase production, however; focussing on mussels as an alternative protein resource for fish food production.

\section{Norway}

Although the blue mussel is found along the entire Norwegian coast from Sweden to Russia, production has yet to reach commercial viability. The main reasons for this are low prices, logistical problems, as well as problems with bird predation and marine biotoxins caused by algal blooms. Other shellfish production of the European flat oyster (O. edulis), both of juveniles and market size, has a long tradition in Norway, and the Pacific oyster (C. gigas) has also been imported for aquaculture purposes, but neither of these have reached any significant production volume. Experiments in the cultivation of the great Atlantic scallop ( $P$. maximus) has also been on-going for a number of years but commercial production has not yet been established.

Iceland

In Iceland the mussel (M. edulis) culture industry is a rather new player (Gunnarsson et al. 2005; Thorarinsdóttir et al. 2007). Today two production areas are harvested and other small scale, experimental culture sites are located around the island, with the exception of the south coast. In all cases spat from artificial collector ropes is used for cultivation. However, fishermen have begaun transferring wild mussels from natural banks to licensed culture sites for growout. Transfers are conducted to shorten culture time and are reported from several places around the island. Recently, about 200.000 juvenile oysters (C. gigas) were transfered from a Spanish hatchery with permission of the Icelandic Food and Veterinary Authority to start cage cultivation on an experimental scale in northern Iceland. Permission was given assuming that the $8^{\circ} \mathrm{C}$ maximum temperature in summer at the new cultivation site would prevent the oysters from reproducing. There was no public discussion or consultation with the national scientific community before this transfer occurred. 
Tab.1: List of most relevant bivalve species transfered in Atlantic Europe for aquaculture purpose and the level of translocation ( $L=$ Local, $N=$ National, $R=$ Regional (European economic region) and I = International (between economic regions/ worldwide)).

\begin{tabular}{|c|c|c|c|c|c|c|c|c|c|c|c|c|}
\hline Transfered Species & Belgium & Denmark & France & Germany & Iceland & Ireland & Netherlands & Norway & Portugal & Spain & $\begin{array}{c}\text { Sweden } \\
\text { (west coast) }\end{array}$ & UK \\
\hline Mytilus ed ulis & L, N & $L, N, R$ & $L, N, R$ & $L, N, R$ & L, N & $L, N, R$ & $L, N, R$ & $L, N, R$ & & & $L, N$ & $L, N, R$ \\
\hline Mytilus galloprovincialis & & & $L, N, R$ & & & & & & L, N & $L, N, R$ & & \\
\hline & & & & & & & & & & & & \\
\hline Crassostrea gigas & $L, N, R$ & & $L, N, R, I^{*}$ & $L, N, R$ & & $L, N, R$ & & $L, N, R$ & $L, N, R$ & $L, N, R$ & & \\
\hline Ostrea edulis & $L, N, R$ & $L, N, R$ & $L, N, R$ & & & $L, N, R$ & & & & $\mathrm{~L}, \mathrm{~N}, \mathrm{R}$ & & \\
\hline & & & & & & & & & & & & \\
\hline Ruditap es philip pinarum & & & $L, N, R$ & & & & & & $L, N, R, I^{\star \star}$ & $L, N, R$ & & \\
\hline Ruditap es decussatus & & & $L, N, R$ & & & & & & $L, N, R$ & $L, N, R$ & & \\
\hline & & & & & & & & & & & & \\
\hline Cerastoderma edule & & & $L, N$ & & & & & & $L, N, R$ & & & \\
\hline Mercenaria mercenaria & & & L & & & & & & & & & \\
\hline & & & & & & & & & & & & \\
\hline Pecten maximus & & & $L, N, R$ & & & & & $\mathrm{~L}, \mathrm{~N}, \mathrm{R}$ & & & & \\
\hline
\end{tabular}

*spat transfer from the EU

${ }^{* *}$ spat \& adults transfer into the EU

\section{Relevant guidelines and legislation}

It is clear that bivalve shellfish transfers can pose significant potential threat to the health of a marine ecosystem thus it is essential that tools be in place, including statutory national and European legislation, to assess and minimise the risks to bivalve shellfish cultivation while establishing the means of measuring success. As shown in the following paragraphs, global and regional binding agreements only contain general obligations, while EU legislation delivers detailed rules and standards. Figure 1 illustrates the interaction between the different layers of legislation. This legal "cascade system" (Czybulka 2007) portrays the complexity of environmental governing, where fragmentary impulses are sent from the topmost cascade, the global international law. At lower levels, these impulses should be specified and advanced without neglecting the primary purpose. 
Fig. 1: Illustration of the interaction of the different layers within the legal "cascade system" displaying the complexity of environmental governing. Fragmentary impulses are sent from the topmost cascade, the global international law to lower levels, where impulses are specified and advanced without neglecting the primary purpose.

\subsection{Global International Law}

3.1.1. The UN Convention on the Law of the Sea (LOSC)

Part XII of the global UN Convention on the Law of the Sea (UNLOSC 1982) deals with the states' general obligation "to protect and preserve the marine environment", Art 192 LOSC. According to Art 194 para. 1 LOSC, measures by the states must be taken to "prevent, reduce and control pollution of the marine environment from any source". Art 194 para. 2 LOSC requires the states to prevent environmental pollution on their territory from spreading to other states. Art. 208 LOSC is relevant for shellfish introductions to aquaculture activity on the seabed. States should enforce laws and regulations and other measures to prevent, reduce and control pollution of the marine environment. These "laws, regulations and measures shall be no less effective than international rules, standards and recommended practices and procedures", Art. 208 para. 3 LOSC. The aim of the directives is to ensure that national standards meet the standards of FAO Code of Conduct (FAO 1995) and the ICES Code of Practices (ICES 2005) which are discussed below.

The term "pollution" is defined in Art. 1 para. 1 no. 4 LOSC as the "introduction by man, directly or indirectly, of substances or energy into the marine environment." Assuming that species, pests and diseases count as "substances" in this sense, the spread of domestic organisms transmitting diseases or parasites is covered within the term "pollution". Hence, the impact of domestic diseases and pests on wild populations should be subject to Art. 194 para. 1 and 2 LOSC.

If, intentionally or accidentally, non-domestic or non-resident species are transfered, states need to consider Art. 196 LOSC: "States shall take all measures necessary to prevent, reduce and control 
pollution of the marine environment resulting from [...] the intentional or accidental introduction of species, alien or new."

The fact that a clear definition of "alien" or "new" species is missing leads to several problems in practice (McConnell 2002). Additionally, Art. 196 para. 1 LOSC requires "significant and harmful changes" to make this norm applicable. Furthermore, Art. 194 para. 5 LOSC offers a more extensive approach to the protection of ecosystems (Czybulka 1999). If the transfer of bivalve shellfish and its consequences threaten "rare or fragile ecosystems" or the "habitat of depleted, threatened or endangered species and other forms of marine" coastal states are obliged to take measures to protect those ecosystems and habitats, and these measures must be adequate. The states' obligations in environmental protection are secured by liability rules. According to Art. 235 and 304 LOSC states are liable for the fulfilment of international obligations for the protection and conservation of the marine environment.

\subsubsection{The Convention on Biological Diversity (CBD)}

Similarly to the LOSC, the Convention on Biological Diversity (CBD 1992) is a binding umbrella convention, which leaves the details of the rules of implementation to the member states. The protection of biological diversity is a comprehensive objective, which comprises three sub-areas; the protection of biodiversity, genetic diversity and the diversity of the ecosystems. Art. 8 CBD lists a number of different actions to be taken by states and which concern the movement of bivalves. Under Art. $8 \mathrm{~h}$, member states should "prevent the introduction of, control or eradicate those alien species which threaten ecosystems, habitats or species". Unfortunately, the crucial terms "alien", "species" and "threaten" are not precisely defined in the binding convention text. The conference of the parties (COP, the governing body of the CBD) has adopted guidelines for the implementation of Art. 8 CBD. The "Guiding Principles for the Prevention, Introduction and Mitigation of Impacts of Alien Species that Threaten Ecosystems, Habitats or Species" (CBD 2002 CoP 6 /23) should be of special interest for the movement of bivalves, although these principles are "soft law" and not legally binding. Nevertheless noteworthy, we find an emphasis on the precautionary principle which obliges the states to take up preventive regulations e.g. for a risk analysis if there is scientific doubt whether there will be any ecologically adverse impact. The European Union as member of the CBD has implemented some of the provisions of $C B D$ and COP 6 / 23 within the binding Regulation (EC) 708/2007.

\subsubsection{FAO Code of Conduct for Responsible Fisheries (CCRF)}

The Code of Conduct for Responsible Fisheries (FAO 1995) provides general principles and standards of conduct for the management and development of fisheries and aquaculture. The code is not legally binding, but as mentioned above, because of Art. 208 para. 3 LOSC the CCRF must be considered the standard by which states must comply. Art. 9.1 CCRF calls for states to establish, maintain and develop an appropriate legal and administrative framework which facilitates the development of responsible aquaculture. Transboundary aquatic ecosystems should be protected by supporting responsible aquaculture practices within their national jurisdiction and by cooperation in the promotion of good husbandry and biosecure practices to promote sustainability, Art. 9.2.1 CCRF. It also proposes that "efforts should be undertaken to minimize the harmful effects of introducing nonnative species or genetically altered stocks used for aquaculture" and that states should "promote steps to minimize adverse genetic disease and other effects of escaped farmed fish on wild stocks", Art. 9.3.1 CCRF.

\subsubsection{ICES Code of Practice on Introductions and Transfers of Marine Organisms}

The scope of the code (ICES 2005) extends to human activities which are associated with the introduction and movement of marine organisms. The aim of the recommendations is to protect indigenous in addition to deliberately introduced species. An important tool to avoid risk in the transport of species is quarantine measures. These are part of a proposed multi-step process which includes mitigation, monitoring and surveillance measures. 
At the European Union level, significant elements of the Code of Practice are implemented by Regulation (EC) No 708/2007 concerning use of alien and locally absent species in aquaculture (see below).

\subsection{Regional International Law}

3.2.1. Convention for the Protection of the Marine Environment of the North-East Atlantic (OSPAR Convention) possible steps: to prevent and eliminate pollution and shall take the necessary measures to protect the maritime area against the adverse effects of human activities; to safeguard human health and to conserve marine ecosystems, and, when practicable, restore marine areas which have been adversely affected." The transfer of shellfish for the purpose of aquaculture should be covered by the human activities recognized in Annex $\mathrm{V}$ in conjunction with Appendix 3, which are to be limited appropriately because of their actual and potential effects on marine ecosystems and marine biodiversity. The movement of bivalves would have to have "actual and potential" adverse effects on specific species, communities, habitats or ecological processes. Furthermore the effects have to be irreversible or durable.

So far no measures are known in this respect. The OSPAR Report 2009 Assessment of Impacts of Mariculture (OSPAR 2009) recommends the use of local species for bivalve cultivation. Specific legal measures are not known, which is unfortunate because the OSPAR-Regime could be an appropriate basis to establish coordinated legislation for bivalve transfers throughout the north-east-Atlantic.

\subsubsection{European Law (Treaty on European Union (TEU), Treaty on the functioning of the European} Union (TFEU))

Within the European Union legislative acts, there are rules relating to the movement of bivalves; yet member states are free to determine an individualized application, as we see in Art. 288 of the TFEU (TFEU 2008). "A regulation shall have general application. It shall be binding in its entirety and directly applicable in all Member States. A directive shall be binding, as to the result to be achieved, upon each Member State to which it is addressed, but shall leave to the national authorities the choice of form and methods." Therefore directives require to be transposed into national regulation to enable their implementation.

Environmental protection falls within the range of shared legislative responsibility and results from Art. 4 para. 2 e TFEU. With application of the subsidiary principle of Article 5 para. 3 TEU (TEU 2010), the Community contributes to environmental protection (Messerschmidt 2011).

3.2.2.1. The Water Framework Directive (the Directive (EC) 2000/60/ of the European Parliament and of the Council of 23 October 2000 establishing a framework for Community action in the field of water policy (WFD))

The WFD covers coastal waters to the extent of one nautical mile stretch from the base line, Art. 2 para. Nr. 7 WFD. In Art. 4 WFD are substantial environmental aims, primarily to achieve good ecological status and good surface water chemical status by 2015. The concept of the good ecological status of surface water consists of significant biological (see Annex $\vee$ 1.1.4), hydro-morphological and physico-chemical quality elements. Additionally, the habitat condition is relevant. (Messerschmidt 2011) As described above, it seems likely that the movement of bivalves implies threats which lead to risks to the "good ecological status".

3.2.2.1. Directive (EC) $2008 / 56$ / establishing a framework for community action in the field of marine environmental policy (Marine Strategy Framework Directive (MSFD))

The MSFD supplements the EU legislation on the protection of water bodies by enhancing the WFD. Consequently, the Exclusive Economic Zone as well as all coastal waters (unless they are covered by the WFD) are part of the MSFD, Art. 3 No. 1 a and b MSFD. Throughout the development and implementation of marine strategies at the level of Member States the marine environment shall be protected and preserved, preventing its degradation and impaired ecosystems must be restored. Moreover adverse-impact introductions in the marine environment should be reduced and prevented, 
see Art. 1 No. $2 b$ MSFD. The Directive specifically requires member states to develop vigorous plans of action for marine waters which would include: an assessment (Art. 8), a determination for 'good environmental status' (Art. 9), and the establishment of environmental targets (Art. 10). In particular a list of stress/pressure points and adverse impacts in Annex III Table 2 shall be considered. Aquaculture, here primarily the intensive cultivation of fish in open sea cages, is seen as pressure in the context of nutrient enrichment, not in the distribution of alien species or pests and diseases. These are listed under the term "biological disturbance": The "introduction of microbial pathogens, introduction of non-indigenous species and translocations".

\subsubsection{Council Regulation (EC) 708/2007 concerning use of alien and locally absent species in aquaculture}

The general clause Art. 4 of Regulation 708/2007 requires the member states to ensure that "all appropriate measures are taken to avoid adverse effects to biodiversity, and especially to species, habitats and ecosystem functions which may be expected to arise from the introduction or translocation of aquatic organisms and non-target species in aquaculture and from the spreading of these species into the wild." The regulation draws attention not only to translocated aquatic organisms, but also to "non-target" species. Non-target species are defined in Art. 3 No. 8 as "any species or subspecies of an aquatic organism likely to be detrimental to the aquatic environment that is moved accidentally together with an aquatic organism that is being introduced or translocated not including disease-causing organisms which are covered by Directive (EC) 2006/88/EC." Notably, the European Union has taken notice of "hitch hiker species, infectious agents and toxic algae". Aquaculture farmers who intend to introduce (non exempted) alien and locally absent bivalves must obtain permission from the competent authority following Art. 6 . In doing so the responsible authority will have to differentiate between "routine movements" according to Art. 8 and "non-routine movements" according to Art. 9. A 'non-routine movement' defined in Art. 3 No. 16 and 17 means the movement of aquatic organisms from a source which has a low risk of transferring non-target species and which, on account of the characteristics of the aquatic organisms and/or the method of aquaculture to be used, might give rise to adverse ecological effects.

In the case of a non-routine movement an environmental risk assessment shall be carried out as outlined in Annex II. Permits will only be issued when the risk assessment report, including mitigation measures, indicates low risk to the environment, Art. 9 para. 4. The definition of "risk" is provided throughout the assessment by a standardized process which involves the potential of genetic and ecological impact as well as the potential of introducing non-target species. If scientific uncertainty is evident the precautionary principle should be applied. In addition to the risk assessment, in the case of a non-routine movement into open aquaculture systems, Art. 15 para. 2, 3 and 4 must be considered. Here, the bivalves must be kept in a designated quarantine facility. Only progeny of the introduced aquatic organisms may be used in the aquaculture facilities of the receiving Member State, provided that no potentially harmful non-target species are found during quarantine. Adult stock may be released in those cases where the organisms do not reproduce in captivity or are fully reproductively sterile, providing confirmation of the absence of potentially harmful non target species. Following the non-routine movement, species shall be monitored after their release into open aquaculture facilities, for a period of two years or for a full generation cycle, whichever is longer, Art. 18, 22 Regulation (EC) $708 / 2007$.

These rules however, have exceptions, some species are excluded. Art. 2 para 5 states that this regulation shall not apply except for the general clause in Art. 4 to the species listed in Annex IV. Hence the bivalves $C$. gigas and $R$. philippinarum listed in Annex IV can be moved without any risk assessment or quarantine. Moreover the regulation does not consider triploid organisms in the definition of Art. 3 para. 5. The regulation is not therefore applicable to those types. Also the regulation does not apply to movements of locally absent species within the Member States "except for cases where, on the basis of scientific advice, there are grounds for foreseeing environmental threats due to the translocation, Art. 2 para. 2. 
3.2.2.4. Directive (EC) $2006 / 88$ on animal health requirements for aquaculture animals and products thereof, and on the prevention and control of certain diseases in aquatic animals

Directive (EC) 2006/88 requires Member States to authorize aquaculture businesses. The permit is issued if authorisation conditions under Article 5, 8, 9 and 10 are met. Article 8 considers traceability and requires an accurate record of the movement and mortality of animals and the results of the riskbased animal health surveillance program detailed under Article 10. Article 9 deals with the establishment and implementation of "good hygiene practice". A permit is granted only if the aquaculture operation remains under the supervision of the responsible authority. Under Article 5 para. 2 , the authorization will not be granted: "if the activity in question were to lead to an unacceptable risk of spreading diseases to farms, mollusc farming areas or to wild stocks of aquatic animals in the vicinity of the farm or mollusc farming area"

However, before a decision is made to deny authorization, consideration shall be given to riskmitigation measures, including possible alternative locations for the activity in question, Article 5 para 2 subpara. 2. Which risks are acceptable and which are not is not defined in the Directive; these should be identified, assessed and rated in the processes associated with each farm site, mitigating measures should be developed and included in a site biosecurity measures plan. For the marketing of aquaculture animals and products thereof, the provisions of Articles 11 et seq apply. In this chapter detailed rules on the movement of aquaculture animals between Member States, zones and compartments with different health status are described. According to Art. 12 para. 1, Member States ensure the health of aquatic animals after arrival at the destination regarding the diseases listed in annex IV part II. For bivalves diseases include infection with Bonamia exitiosa, Perkinsus marinus, and Microcytos mackini. Art. 14 requires a health certificate if animals are moved for the purpose of farming or restocking are moved into an area which is declared disease-free in accordance with or subject to surveillance, or eradication programmes. According to Art. 20, wild aquatic species which are caught in areas that have not been declared free of the diseases shall be quarantined under surveillance of the responsible authority. This applies only to the species listed in Annex IV, Part II.

Under Art. 17 Member States shall ensure that the living animals of vector species to be introduced should be held in quarantine for a reasonable period. This rule applies to other than the species listed in Annex IV, Part II as we will see in Regulation (EC) 1251/2008. Throughout the (directly applicable) Regulation (EC) 1251/2008 the Commission has adopted rules for implementing the Directive (EC) $2006 / 88$ to the extent of certification and requirements for import and marketing as well as stipulating a list of vector species. Here bivalves are only vector species under Art. 17 if they are listed in column 2 of Annex I Regulation 1251/2008. This list includes major vector species for the following bivalve related diseases: Infection with $B$. exitiosa, Taura-Syndrom, Yellowhead-Disease, Infection with Marteilia refringens, infection with Bonamia ostreae and White-Spot-Disease. Bivalve vector species shall be treated as mentioned in Art. 17 Directive (EC) 2006/88.

3.2.2.5. Directive (EC) 2004/35 of the European Parliament and of the Council of 21 April 2004 on environmental liability with regard to the prevention and remedying of environmental damage

The Directive (EC) $2004 / 35$ is a regulative liability system that completes the common environmental law. According to Art 1 Directive (EC) 2004/35 the objectives are to establish a framework of environmental liability based on the "polluter-pays" principle, to both prevent and remedy environmental damage. The term environmental damage as referred to in Art 2 No. 1 Directive (EC) $2004 / 35$ comprises damage to water, soil and protected species or natural habitats. The Directive is applicable in the marine sector including the EEZ (Czybulka 2008). The scope of application is also inclusive of environmental damage that occurs in the course of professional activities listed in annex III. With regard to harm of protected species or damage to natural habitats, the types of injury which occur in the course of professional activities other than those named in Annex III are included. In this case, however, the damage must be caused deliberately or negligently according to Art. 3 para. 1 lit. b). The transfer of bivalves should be classified as "other professional activity" according to Art. 3 para.1 lit.b) if it causes damage to protected species or natural habitats. Art. 8 deals with the costs. In general, the operator has to bear the costs of prevention or remediation measures. 


\subsection{National Law}

Member states of the EU are required to follow rules and regulations as listed above, yet environmental and animal health legislation which exist at the lowest rung of the "cascade system" remain the most dominant and influential regulatory apparatus. Farmers must apply for and receive the appropriate permits from the locally responsible authorities. Although influenced by the higher levels national legislation differs greatly in the Northeast Atlantic. EU directives are also not implemented uniformly. The problem also exists that countries outside of the EU will have their own directives, thus transfer activity is also impacted by such laws which are beyond the scope of this review.

The federal system of states within Germany also creates variation in legal requirements; for example the strictest rules covering bivalve transfer activity would likely be those from the German region of Schleswig-Holstein. Regulations here ban transfer activity which cannot prove that no harm is done to the environment. In the German region of Lower Saxony however regulations require shellfish farmers only to prevent the possibility of spreading mussel disease. Germany is a good example of how national approaches to legal procedures covering environmental health are complex and differ widely especially throughout the Northeast Atlantic.

\section{Records and Traceability}

To fulfil records and traceability requirements, article 8 of the Directive (EC) 2006/88 requires that member states shall ensure that all farms rearing bivalve molluscs are registered by the official service and records of live bivalve molluscs entering the farm, and information relating to their delivery, numbers/weight, size and origin, must be kept. Similar records must be kept for bivalve molluscs leaving the farm for re-immersion, containing all information relating to their dispatch, their number or weight, size and destination, and any observed abnormal mortality. These records, which are open to scrutiny by the official service at all times, on demand, are updated regularly and kept for four years. Movements of susceptible shellfish from outside the EU are required to be accompanied by a suitable animal health certificate, signed by the responsible authority, while a trace notification message is generated electronically at source. This trace message system was designed to improve the management of animal movement both from the outside and within the EU, creating a better tool for managing animal disease outbreaks. It was issued by the responsible authority in the EU for consignments that require a health certificate (susceptible or vector animals introduced into a Category I (Disease-free), II (Surveillance Programme) or IV (Eradication Programme) country/compartment) - for farming, relaying, restocking and further processing for human consumption. In addition, movements for farming or restocking that do not require a health certificate must have a traces message. Basically, shellfish movements, other than those directly destined for human consumption, should be recorded in the trace-system within the EU and for imports into the EU. Directive (EC) 2006/88 not only requires that aquaculture production businesses keep records of all movements of shellfish to and from their sites, but also that these records should be kept by other shellfish-associated businesses, including depuration plants which are responsible for the inspection and processing of shellfish subject to disease control measures and certain specialist transporters of aquaculture animals. These records would include all movements of seed shellfish to shellfish farms, movements between farms and also movements from farms to the place of final processing. However, these records do not provide information on ecological impact, or effects on genetic integrity and risks of introduction and spread of invasive species. There is a provision in the regulations that would allow shellfish farmers who share the same mollusc farming areas to apply for a shared authorization. This reflects the spatial distribution of farms within hydrographic areas, and the effect of this on the potential spread of disease within these areas. There is a provision for eradication programmes for listed diseases when they are confirmed in a member state. 


\section{Discussion}

There is a perceived need amongst the European scientific community for a more targeted, risk-based assessment of movements of bivalve molluscs for relaying, within the EU, for commercial purposes. These risk assessments should include all possible effects of diseases (parasites, viruses and bacteria), hitch hiking species and genetic contamination including the risk to native stocks from interbreeding. Because of the unknown risks of certain introductions the emphasis should be on precaution. If the transfer of a species is allowed, it should be in quarantine - even through the F1 generation to assess reproductive behaviour and danger of disease transmission, prior to its release. Global (LOSC, CBD) and regional (OSPAR) binding agreements do not offer a broad solution but leave it to the member states to find sufficient standards. The EU has taken over the task to prevent environmental damage through bivalve transfers. The CCRF and the ICES-Code of Practice regulations indicate that EU legislators understand the serious risks posed by the spread of serious disease, yet the potential for adverse environmental impact (other than the spread of certain diseases) is currently not adequately addressed through existing legislation. Regulations need increased focus on the prevention and control of transfers of undesirable alien species. It seems clear that no blanket exclusions for economically important species should be made (C. gigas), and all likely risks inherent with transfers within and among member states should be given due consideration.

Part B of Annex III of the Council Directive 2006/88/EC considers surveillance inspections on site. Surveillance and frequency are dependent on the known health status of a member state and risk level combined with their adherence to the site's biosecurity measures. Passive and intelligence-based surveillance together with training awareness, as well as providing advice to operators on aquatic animal health issues, will play an essential part in the success of such models. Frequency of inspections are determined by the health status of the member state regarding diseases; and the risk level of the farm or mollusc farming area in relation to the contracting and spreading of diseases. The health status is differentiated into categories, such as: disease-free; not disease-free but subject to surveillance programme; not known to be infected but not subject to surveillance programme; infected but subject to an eradication programme; known to be infected, subject to minimum control measures. The risk level is determined by evaluating risk factors such as e.g. type of production, number of species kept, quality of bio-security system, competence of staff and risks posed by human activity, predators or birds in the vicinity of the farm. By using such a complex system farms can be classified according to their risk level. This classification will help to determine the level and intensity of surveillance and inspection required.

On a positive note the EU has issued some legislative acts which are applicable towards transfer of bivalves. The regulation (EC) 708/2007 regarding "non-routine movement" requires that a risk assessment with specific procedures should be performed. As defined, the risk assessment could be an appropriate tool to prevent possible environmental threats. However, the regulation (EC) 708/2007 may be limited by the exclusion of certain target species, including $C$. gigas and $R$. philippinarum, which can be moved without additional monitoring and does not include triploid species. Moreover transfers between member states are not bound legally with the same control as those which cross national borders. Notwithstanding, it is important to note that while a risk assessment may not be applied to species listed in Annex IV (of EC/708/2007), exceptions can be made in cases where member states wish to take measures to restrict certain species in their territory. Ecological considerations may force such measures.

However varying procedures, rules and regulations throughout the north-east Atlantic, and how strictly these are enforced or not enforced, gives rise for concern. Because transfer activity will invariably involve different regions and states, most optimally these should work together cooperatively on a legislative level to maximize efficiencies and competency. In all ICES member states there are many pieces of legislation governing activities in the marine environment. However, it is the case that some pieces of legislation operate in isolation and fail to identify efficiencies that might be found by consideration of additional legislation, be it transnational or national. For example, the fish health Directive (EC) 2006/88 requires that shipments are inspected at the point of departure to ensure that the requirements of the Directive are met, i.e., no risk material is present in the shipment. This validation is provided on the basis of inspection at the point of origin and requires the identification of 
potential carrier organisms of listed diseases in the shipment. Listed diseases are divided into two categories; exotic and non-exotic, although Article 43 considers provisions for limiting the impact of diseases which are not listed, such as emerging diseases. For bivalve molluscs the exotic diseases are listed as: infection with $B$. exitiosa, Perkinsus marinus and Microcytos mackini. The non-exotic diseases are listed as: infection with $B$. ostreae and $M$. refringens. While the shipment form offers a place for the identification of biofouling organisms or vectors, it only specifies that problem species should be listed and does not have authority to restrict movement stock in the event of non-target species being present. The authorization does not request that all non-target species should be listed. For example Urosalpinx cinerea, Credipula fornicata or Mytilicola spp are not listed pests, although they are recognized as serious pests among certain member states, as in France, Brittany (Grall \& Hall-Spencer 2003), and in Spain, Galician Rías (Sánchez Mata 1996, Blanchard 1997) for C. fornicata. Thus, unless consignments are refused entry by farmers on commercial grounds, consignments of infested bivalves can be relayed within and between member states and third countries, uncontrolled. An opportunity is presented here to fulfil some other national legislative requirements by listing all non-target species found in shellfish consignment. Such a requirement would be to identify non-native species that might be imported into an area with a consignment of shellfish. These lists could easily be implemented in the existing EU legislation mentioned above, but also should be adopted by states in Atlantic Europe outside the EU.

A problem which must be addressed is lack of enforcement of existing rules: an example is pathogen organisms (such as ostreid herpes-virus OsHV-1) may have been transferred from areas undergoing increased mortality, simply because the ban on transfers (included in Directive 2006/88/EC) had not yet been confirmed and imposed by national authorities.

Furthermore new EU provisions are planned (EU Commission 2013) to manage the introduction and spread of alien species in general. Concerning aquaculture however they regard to the criticised regulation (EC) 708 / 2007Altogether the EU legislation as well as differing national handlings reveal some weaknesses. A cooperative approach and the promotion of steps establishing consistent procedures without exceptions for relevant species will achieve significant progress in the prevention of ecological impairment to the environment. In contrast, isolated bans of transfer activities as happened in the German region of Schleswig Holstein might not be desirable. Broader perspectives are needed to find solutions. Therefore a cooperative approach towards bivalve transfer activities throughout the entire north-east Atlantic should be considered. The OSPAR-Regime which covers all adjacent states of the north-east Atlantic could offer an appropriate legal mechanism.

\section{Recommendations}

Shellfish aquaculture is, like any other sector, focused on a positive economic return and related environmental issues such as the health of the maritime bodies of water and transfer of shellfish from one area to another are often not of major concern. This short-sightedness can potentially have devastating impact on shellfish farming operations or marketing of large numbers of growers if the introduction of disease is facilitated through illegal transfers of non-disease certified shellfish from area to area, state to state, or country to country. While such activity may seem innocuous enough to the non-informed grower, there are also far reaching biosecurity issues which surround these illegal activities. Good husbandry and biosecurity practices are essential to successful prevention and control of pests, parasites, fouling organisms and disease, with associated benefits in production and profit. Record keeping of farming activities is integral in some shellfish culture businesses, but in others, they may be non-existent. Growers should have some kind of personal recordkeeping and documentation of inputs, transfers and outputs of their operation. If tainted shellfish are found in the marketplace or if a previously unrecorded disease-causing organism, predator species, or non-indigenous species shows up in an area, reliable data about seed or adult shellfish can help to avoid further transmission problems. Recordkeeping and data collection can be supplemented by the capture and recording of environmental data (wind, weather, water temperature, salinity, dissolved oxygen) which may assist a grower in understanding how his crop is interacting with the marine environment. All of this can form part of a Code of Practice that the industry could voluntarily adopt to acknowledge that they are 
operating in an environmentally sound way. This would be a good protection against biosecurity issues which may have far reaching economic and biological implications.

It is important that aquaculture operators be made fully aware that biosecurity infractions will be handled strictly by enforcement agencies and if in violation of any legislation or regulation will be prosecuted to the full extent of the law. In addition, growers who knowingly ignore illegal activities by other growers should be made to understand that their silence ultimately makes them compliant with the illegal activity, and subjects their businesses to harm if not reported to the appropriate agency. It is also important to point out to growers that the implications of ignoring illegal introductions, transfers of shellfish from non-approved waters, or by-passing any regulatory protocol could lead to significant negative effects for growers not only in the local area, but more broadly at the national and regional levels. More specifically, industry operators need to understand what the negative biological implications, ecosystem health impacts, and human health risks may be when operating outside of the regulatory framework. Understanding the long term view and adhering to a standard code of practice by the individual growers, groups of growers, and the industry in general, is vital for a protected continuation and sustainability of the shellfish culture businesses.

Risk assessment methodologies have been developed for a range of scenarios covering disease, nonnative species, and methodological innovation. These risk assessments need to be standardised, updated and applied. In addition, they need to be available to the industry, to minimize the impact of transfers and to prevent the introduction of invasive species, and for development of contingencies to minimize their impact and plans to eradicate introductions. Farmers need to consider legislation and codes of practice appropriate to them, their application, risks, their mitigation and to develop a practical plan appropriate for themselves, i.e. good hygiene practice as relevant for the activity concerned to prevent the introduction and spreading of diseases. An example of a practical plan for shellfish farmers including advice on hygiene, biosecurity and good husbandry practices, risks factors and their mitigation is provided by Fraser (2010).

A credible and open dialogue between the shellfish sector, agency and policy makers needs to be maintained to best educate and implement biosecurity measures. Understanding of the economic implications of harmful or illegal activity, by both those responsible for protecting the environment and the shellfish industry, will only bring substantial benefits over time. To understand that prevention costs less is an important aspect of this. Policy makers and policy enforcers must grasp the fundamental reasons for why industry might be tempted to act illegally during any part of the shellfish culture or processing sectors. Production schedules, market demand, opportunistic illegal sources of product may appear to be effective cost cutting measures by industry in the short term; yet policy makers and law enforcement need to communicate that these actions can actually have a more significant negative economic impact over the long-term. Abiding by regulations developed on the basis of sound scientific studies would take a much larger perspective into account and allow for sustainability.

An example of informative dialogue to promote sustainable and improved results over the long term is the Cooperative Extension Service established in the late 19th century in the United States, with the aim to improve food agricultural production by transferring the research results to the users on the farms. The central element of this process were agricultural agents, individuals with advanced degrees in the agricultural sciences, who served as liaisons between science, policy and the intended audience for that research, the farmer. Since this format was very successful, it was expanded in the early 1970s to commercial fishing and aquaculture industries. The central purpose of the agents is to educate fishermen or aquaculturists on the most up-to-date scientific results and to facilitate positive behavioural changes. The agent remains separate from the natural resource managers and basic researchers, yet must communicate with both to understand what new, good or bad, issues may impact the profitability of the industry. By not having a regulatory capacity, yet being the one who is supplying the managers with the viewpoint of the industry, he remains in the middle, serving as an educator to both sides. Establishing changes through educational training is a time consuming process; however, it can be fruitful once there is cooperation and trust between industry and the agents. We suggest a similar plan for establishing such a type of Cooperative Extension Service within the EU, elucidating how small changes can reduce large impacts, would surely help protect the natural marine resources of the EU, and the shellfish industry. 
In addition to expanding education, the methodology to improve plans for the removal and control of invasive species from transferred stocks must be continually updated and communicated. Thus it should be incumbent upon policy makers to monitor and farmers to report exotic organisms. To achieve such aims a deeper awareness of marine biodiversity in shellfish areas, and for example the ability to distinguish exotic species from indigenous fauna and flora, should be made mandatory. Monitoring networks would be a vital step in this direction. Monitoring programs developed for other purposes (i.e. for microbiological contamination, toxins and for EU directives such as the water framework directive and marine strategy directive) can provide useful information and with some limited adjustments, could be improved to include exotic species recording.

\section{Acknowledgement}

804 This article is partly based on a term of reference formulated by the Working Group on Marine Shellfish Culture of the International Council for the Exploration of the Sea (ICES) for their annual report 2010 (ICES 2010). We would also like to acknowledge the contributions of Jeroen Wijsman and Sandra Joaquim on the Dutch and Portuguese transfer movements. 


\section{References}

Beaumont, A., 2000. Genetic considerations in transfers and introductions of scallops. Aquacult. Int. 8, 493-512.

Blanchard, M., 1997. Spread of the slipper limpet Crepidula fornicata (L. 1758) in Europe. Current state and consequences. Sciencia Marina 61(2), 109-118.

Branch, G.M., Steffani, C.N., 2004. Can we predict the effects of alien species? A case-history of the invasion of South Africa by Mytilus galloprovincialis (Lamarck). J. Exp. Mar. Biol. Ecol. 300, 189215.

Brenner, M., Fraser, D., Van Nieuwenhove, K., O`Beirn, F., Buck, B.H., Mazurié, J., Thorarinsdottir, G., Dolmer, P., Sanchez-Mata, A., Strand, O., Flimlin, G., Miossec, L., Kamermans, P. 2014. Bivalve aquaculture transfers in Atlantic Europe. Part B: environmental impacts of transfer activities. Ocean and Coastal management, in press.

Carman, M.R., Morris, J.A., Karney, R.C., Grunden, D.W., 2010. An initial assessment of native and invasive tunicates in shellfish aquaculture of the North American east coast. J. Appl. Ichthyol. 26(s2), 8-11.

CBD,1992. Convention on Biological Diversity, Rio Janeiro, 5 June 1992, in force 29 December 1993, 31 ILM 822 (1992).

CBD, 2002. Conference of the Parties (COP) 6 / 23, Alien species that threaten ecosystems, habitats or species, The Hague 2002.

Campos, C.J.A., Cachola, R.A., 2006a. Integrated Monitoring improves microbiological quality of bivalve mollusks in southern Portugal. Global Aquaculture Advocate 4, 58-59.

Campos, C.J.A., Cachola, R.A., 2006b. The introduction of the Japanese Carpet Shell into costal lagoon systems of the Algarve (south Portugal): a food safety concern. Internet Journal of Food Safety 8, 1-2.

Czybulka, D., 1999. Naturschutz im Küstenmeer und in der Ausschließlichen Wirtschaftszone. Natur und Recht, 10, 562-570.

Czybulka, D.,2007. The need for research in marine fisheries law. Zeitschrift für Europäisches Umweltund Planungsrecht (EurUP), 1, 21-38.

Czybulka, D., 2008. Die Anwendbarkeit der Umwelthaftungsrichtlinie in der Ausschließlichen Wirtschaftszone und auf dem Festlandsockel. Natur und Recht, 30, 304-311.

DFO, 2006. Department of Fisheries and Oceans Canada: A Scientific Review of the Potential Environmental Effects of Aquaculture in Aquatic Ecosystems. Interaction Between Wild and Cultured Species (T. Landry, M. Skinner, A. LeBlanc, D. Bourque, C. McKindsey, R. Tremblay, P. Archambault, L. Comeau, S. Courtenay, F. Hartog, M. Ouellette and J.M Sevigny). Can. Tech. Rep. Fish. Aquat. Sci. 2450(5), 138pp.

DGRM, 2010. Direcção-Geral de Recursos Naturais. Recursos da Pesca, Report, Série Estatistica, Volume 24 A-B, 180pp.

EC Directive (EC), 2000/60. Directive of the European Parliament and of the Council of 23. October 2000 establishing a framework for the Community action in the field of water policy (Water Framework Directive) (OJ L 327, 22.12.2000).

EC Directive (EC), 2004/35. Directive of the European Parliament and of the Council of 21 April 2004 on environmental liability with regard to the prevention and remedying of environmental damage.

EC Directive (EC), 2006/88. Official Journal of the European Union 24.11.2006 (OJ No L328/14 24.11.2006).

EC Directive (EC), 2008/56. Directive of the European Parliament and of the Council of 17 June 2008 establishing a framework for community action in the field of marine environmental policy (Marine Strategy Framework Directive).

EC Regulation (EC), 708/2007. Regulation of 11 June 2007 concerning use of alien and locally absent species in aquaculture.

EC Regulation (EC), 1251/2008. Regulation of 12 December 2008 implementing Council Directive 2006/88/EC as regards conditions and certification requirements for the placing on the market and the import into the Community of aquaculture animals and products thereof and laying down a list of vector species. 
EC Commission 2013. http://ec.europa.eu/environment/nature/invasivealien/index_en.htm, assessed October 2013

FAO, 1995. Food and Agriculture Organisation of the United Nations. Code of Conduct for Responsible Fisheries, Rome, 41pp.

Forrest, B.M., Keeley, N.B., Hopkins, G.A., Webb, S.C., Clement, D.M., 2009. Bivalve aquaculture in estuaries: Review and synthesis of oyster cultivation effects. Aquaculture 298, 1-15.

Fraser, D. 2010. Biosecurity Measure Plans (BMP) on Shellfish Aquaculture Production Businesses (APBs) Marine Scotland, The Scottish Government, ISSN: 1363-5867, 29 pp.

Grall, J., Hall-Spencer J.M., 2003. Problems facing maerl conservation in Brittany. Aquatic Conservation 13, 55-64.

Grigorakis, K., Rigos, G., 2011. Aquaculture effects on environmental and public welfare - The case of Mediterranean mariculture. Chemosphere, 855, 899-919.

Gunnarsson, V.I., Thorarinsdóttir, G.G., Theodórsson, B., Einarsson, S.M., 2005. Handbók, Kræklingarækt á Ísland. Veidimalastofnun, Reykjavík, Iceland, 59 pp.

Heath, R.T., Fahnenstiel, G.L., Gardner, W.S., Cavaletto, J.F., Hwang, S.J., 1995. Ecosystem level effects of zebra mussels (Dreissena polymorpha): A mesocosm experiment in Saginaw Bay, Lake Huron. J. Great Lakes Res. 21, 501-516.

ICES, 2005. International Council for the Exploration of the Sea. Code of Practice on the Introduction and Transfers of Marine Organisms, 30pp.

ICES, 2010. International Council for the Exploration of the Sea. Report of the Working Group on Marine Shellfish Culture (WGMASC) 29 March - 2 April 2010, Galway, Ireland, ICES CM 2010/SSGHIE:07.

Lindahl, O., Kollberg, S., 2008. How mussels can improve coastal water quality. Biosciences 5, 1-14.

Laruelle, F., Guillou, J., Paulet, Y.M., 1994. Reproductive pattern of the clams, Ruditapes decussatus and R. philippinarum on intertidal flats in Brittany. J. Mar. Biol. Assoc. U. K. 74(02), 351-366.

McConnell, M., 2002. GloBallast Legislative Review. Final Report. GloBallast Monograph Series No.1. IMO London.

McKindsey, C.,Landry, T., O`Beirn, F., Davies, I.M., 2007. Bivalve aquaculture and exotic species: a review of ecological considerations and management issues. J. Shellfish Res. 26(2), 281-294.

Messerschmidt, K., 2011, Europäisches Umweltrecht. Verlag C.H. Beck, München.

OSPAR, 1992. Oslo and Paris Commission. The Convention for the Protection of the marine Environment of the North-East Atlantic adopted in Paris on 22. September 1992, entered into force on 25. March 1998.

OSPAR, 2009. Oslo and Paris Commission. Assessment on the Impact of Mariculture. Mc Cormack E, Roche C, Nixon E, OSPAR Comission, London, Report, 63pp.

Skurikhina, L.A., Kartavtsev, Y.F., Chichvarkhin, A.Y., Pankova, M.V., 2001. Study of two species of mussels, Mytilus trossulus and Mytilus galloprovincialis (Bivalvia, Mytilidae), and their hybrids in Peter the Great Bay of the Sea of Japan with the use of PCR markers. Russ. J. Genet. 37, 14481451.

TFEU, 2008. Treaty on the Functioning of the European Union ("TFEU"). Consolidated Version of the Treaty on the Functioning of the European Union 2008 O.J. C 115/47.

Thorarinsdóttir, G.G., Gunnarsson, V.I., Theodórsson, B., 2007. Kræklingarækt á İ́slandi. Náttúrufræðingurinn, 76(1-2), 63-69.

TEU, 2010. Treaty on European Union (“TEU post-Lisbon"). Consolidated Version of the Treaty on European Union 2010 O.J. C 83/01.

UNCLOS, 1982. United Nations Convention on the Law of the Sea. Adopted by the 3rd UN Conference on the Law of the Sea and opened for signature at Montego Bay, Jamaica, on 10 December 1982, entry into force in November 1994.

Wijsman, J.W.M., Smaal, A.C., 2006. Risk analysis of mussels transfer. C044/06, Wageningen Imares, Yerseke.

Wijsman, J.W.M., Tamis, J.E., Kaag, N.H.B.M., Karman, C.C., Foekema, E.M., Smaal, A.C., 2007a. Risk analysis on the import of mussels from Norway into the Wadden Sea. C102/07, IMARES, Yerseke. 
Wijsman, J.W.M., Tamis, J.E., Kaag, N.H.B.M., Karman, C.C., Foekema, E.M., Smaal, A.C. 2007b. Risk analysis on the import of mussels from Sweden into the Wadden Sea. C103/07, IMARES, Yerseke.

Wijsman, J.W.M., De Mesel, I. 2008. Risk analysis on the import of mussels from the Limfjord and the Isefjord (Denmark) to the Oosterschelde. C068/08, IMARES, Yerseke. 